\title{
From the children's author to the adult author: a story of the cycle(s) of the authorship(s)
}

Helena Barbosa helenab@ua.pt ID+ Research Institute for Design and Media Culture; Departamento de Comunicação e Arte, Universidade de Aveiro, Portugal

\section{Reference}

Barbosa, Helena; (2012) "From the children's author to the adult author: a story of the cycle(s) of the authorship(s)", p 137-141 . In: Barbosa, Helena; Quental, Joana [Eds]. Proceedings of the 2nd International Conference of Art, Illustration and Visual Culture in Infant and Primary Education. São Paulo: Blucher, 2015.

ISSN 2318-695X, ISBN: 978-989-98185-0-7 DOI 10.5151/edupro-aivcipe-27

Resumen

De un trabajo realizado anteriormente, el artigo tiene la intención de profundizar algunos contenidos centrados en cuestiones de autoría. Para ello, revela algunos ejemplos de la producción de la cultura material que se convirtió en referencia en mi infancia y también influyó mi viaje en la adolescencia hasta la edad adulta. El artigo describe una historia acerca de mi expresión gráfica durante ese periodo, y relata mis influencias, para mejor comprender no sólo los resultados de mi comunicación visual, pero también realizar algunas decisiones personales que, de alguna manera, involucran el lastre de la importancia del autoría. Se entiende que este estudio comparativo permite darse cuenta de cómo la autoría, mientras la producción de imágenes, desempeña un papel clave en la construcción de identidad y le permite conocer con algunos autores importantes que formaban parte de nuestro universo de la infancia, trayendo a la luces nombres e historias a menudo desconocidas.

Palabras clave autoría, influencias, identidad, diseño portugués

Abstract

From a previously performed work, the paper intends to deepen some content focused on issues of authorship. To do this, the paper reveals some examples of production of material culture that became references in my childhood and that also influenced my path in adolescence until adulthood. The paper also describes a history about my graphic expression in that period and also my influences, to better understand not only the results of my visual communication, but also to contextualize some personal decisions that, in some way, involved the ballast of the importance of the authorship.

It is understood that this comparative study makes it possible to realize how the authorship, while producing images, plays a key role in the construction of identity, and allows to know some important authors who were part of my childhood universe, bringing to light names and unknown histories.

Keywords authorship, influences, identity, Portuguese design

\section{Introduction}

The authorship(s) as reference(s) in the childhood identity construction reveal profound influences that eventually mark the adulthood. The images (visual, mental, sensorial and emotional) are often vehicles for this construction, because they give meanings that go beyond of what we observe. At this level, comes not only experience and the uniqueness of authorship (influences and styles) that we tend to carry in our way of being as children, that become reflected in our professional practice. From this authorship, there is also a personal interpretation and an experience in terms of 'use', that propose links more or less affective with material culture, tracing the path of the identity. Children who are assimilating these 
id International Conference Art, Illustration and Visual Culture in Infant and Primary Education de Arte, llustração e Cultura Visual

na Educação Infantil e Primária

\section{The (in)existence of authors in childhood}

\section{The construction of my authorship from childhood to adolescence}

images, they are also the authors and producers of sense, carrying these authorial influences to adulthood, as well as a set of memories that are associated with the artefacts.

From this small explanation I will try to demonstrate how the production of material culture influenced my choices in terms of my professional practice as a designer and as a professor. In this sense, the paper mentions the importance of identified and anonymous authorship, revealing the names and the artefacts that become references in my professional practice. These examples will help to understand the context that explains the visual discourse of the authors, from the perspective of drawing, and permit to establish an aesthetic parallelism with my personal production. An analysis of these elements will be critical to understand how the inheritance of the images, was visualized, interpreted and materialized in my identity.

The authorship can be realized/materialized in so many ways. In this article, its importance focuses mainly on the realization of images that can be applied in different artefacts, whereas that universe was one of the most that influenced the construction of my personal identity. However, if the material culture always presupposes the existence of an authorship, whether it is anonymous or identified, it's important to understand the meaning (s) and importance (s) that the objects acquired by underlining the authors as 'responsible' for the existence of that material culture.

Why consider the lack of authors in my childhood? During this period I had access to a set of production undertaken by various authors, however, I remember that I always emphasized images and artefacts and never the authors. In reality I do not remember their existence, while producers of culture that had access, and so their names were always absent, though they were present. For me, its production was so attractive and meaningful, that interested me just the outcome of their production. Consequently, the drawings that were made not always carried as the referent the 'authors'.

Despite photographs are an excellent resource for the recovery of the memory, I remember only of situations from the age of four years old. I might say that everything started in the attic of my grandmother's house where my uncle had his atelier and I spent hours with my brothers to draw. In this space, I found in the drawing the best instrument and the more interesting thing to play. The world of pictures fascinated me as well as all the material culture. If on the one hand these references were inspiring, the drawing was an area where I felt safe and happy.

To present a few examples, when I saw my production was possible to identify three types of representation, where the incidence of drawings in thematic terms, somewhat pointed way for what I am today in professional terms. I recognized some difficulty in defining exact boundaries of typologies of drawing that I present below, because it's easy to find 'contamination' between them. Despite this difficulty I decided to define three types of typologies.

The first type concerns the technical drawing. At this level there are two forms of graphic expression, one related with the geometric draw and another with the perception of space. The desire to represent simple shapes such as squares, triangles and other polygonal figures, are visible in many of my draws. As a teenager I usually made draws focusing on exercises on the geometric draw. It was also possible to see the idea of regularity and order, concerns related with the division of the paper, using the geometric design as graphic expression in terms of composition.

The same thing happened with the perception of space. At this level, it is visible the concern to assign to the represented objects the idea of volume, where the perspective as expressive argument, try to get a closer result related with reality. In this sense, the two-dimensional plane acquires a secondary role, and the elements represented are valuing the third dimension. Other examples occur with two records based on technical drawing which are much more abstract and where are represented the top views of the two houses where I lived in Mozambique during 
$2^{\text {nd }}$ International Conference Art, Illustration and Visual Culture in Infant and Primary Education $2^{\circ}$ Congreso Internacional

Arte, llustración y Cultura Visual en Educación Infantil y Primaria
Congresso Internacional

de Arte, llustracão e Cultura Visual

na Educação Infantil e Primária

the 70's. These drawings were made when I was nine years old and they also reveal my interest in geometry.

The second typology is related with the replication of some models that made part of my childhood universe. With this typology was possible to notice the importance of some images and some objects that I had during my childhood and adolescence, making possible to assign two subdivisions for draws inspired by the models. While the first subdivision consists of an idea of replica and was present mainly in my childhood, the other subdivision is related with a more conceptual inspiration without resorting to direct copy, giving a greater degree of freedom of graphic expression that was consolidated with the drawings of my adolescence.

Related with replica, representations were made based on the attempt to reproduce faithfully the selected models, regardless of the results. Consequently, the transposition of a real object for my paper, it was by all means the proof of my ability to reproduce that same object. In reality, the mimesis presented in the drawing was a constant challenge of mine capabilities.

In turn, more conceptual inspiration was based on a personal interpretation on the subject represented, where it didn't matter represent the model as it exists, but yes, represent an intention.

It was found that this typology is characterised above all, by the influence of authors, who played a key role in the construction of my personal identity, for having the ability to amplify the senses and emotions to the production realized. This process is involved not only the author, but also with the receiver or the user who can interpret and feel differently these objects and images, assigning them an emotional charge that should be relevant and becomes part of memory.

Finally, the interest expressed by the draw of the letters and brands, gave rise to identification of third typology. During my childhood, these early forms of expression were part of my graphic speech being present in some drawings. If initially resulted by the copy from the existing words in other artefacts, as was the case with the drawings between four and five years, in turn, the drawings made with eleven years reveal the same interest without resorting to copying, showing various graphic solutions where the strict drawing seems to justify the choices made for the creation of a personal brand through the use of the initials of my name.

\section{The authorship in}

\section{adulthood}

After the identification of the types presented and specified its characteristics with some examples, it is important to present the relationship with adulthood, describing my path as author. In this phase, the solutions fall within these types as for example with the creation of my personal brand, which favours the presence of simple geometric elements, such as the use of the circle, square and triangle.

From the point of view of replication of models is likely to realize some drawings that were based on photographic images and who sought to portray reliably the originals. At the same time, it was found one graphic element that it was used in my own drawings which also served as inspiration for more artistic representations, revealing that the references to represent drawings were not always external.

In terms of typography there is a use of drawings of letters whose final outcome approach to simple geometric shapes, seeking balanced solutions between typography and with the geometric forms that were used.

To establish this comparative study was possible to realize the reasons for joining the Design course during the 80's, and later with the activity while designer and teacher in the degree in Design. The areas of interest are visible and fall mainly into two disciplines that I teach currently. One is related with the geometric draw and the other with the history of Portuguese design, where are referenced many authors who were part of the production of artefacts that I had contact in my childhood. In addition, the interest in Portuguese material culture eventually wake up a specific interest with the poster, giving rise to the research carried out within the framework of the PhD. 
Art, Illustration and Visual Culture in Infant and Primary Education
Arte, Ilustración y Cultura Visual en Educación Infantil y Primaria de Arte, Ilustração e Cultura Visual

na Educação Infantil e Primária
Figure 3 y 4. Left: Cover of the reading book of the 2nd grade of primary school (1975/76) - Book illustrated by Maria Keil and Filipe de Abreu. Right: Pages with an illustration of Maria Keil. Personal archive.

Figure 3 y 4. Left: João Abel Manta (1975) Poster. Archive from Biblioteca Nacional de Portugal. Right: Draw inspired in the poster of João Abe Manta that was offered to my parents (1978). Personal archive.
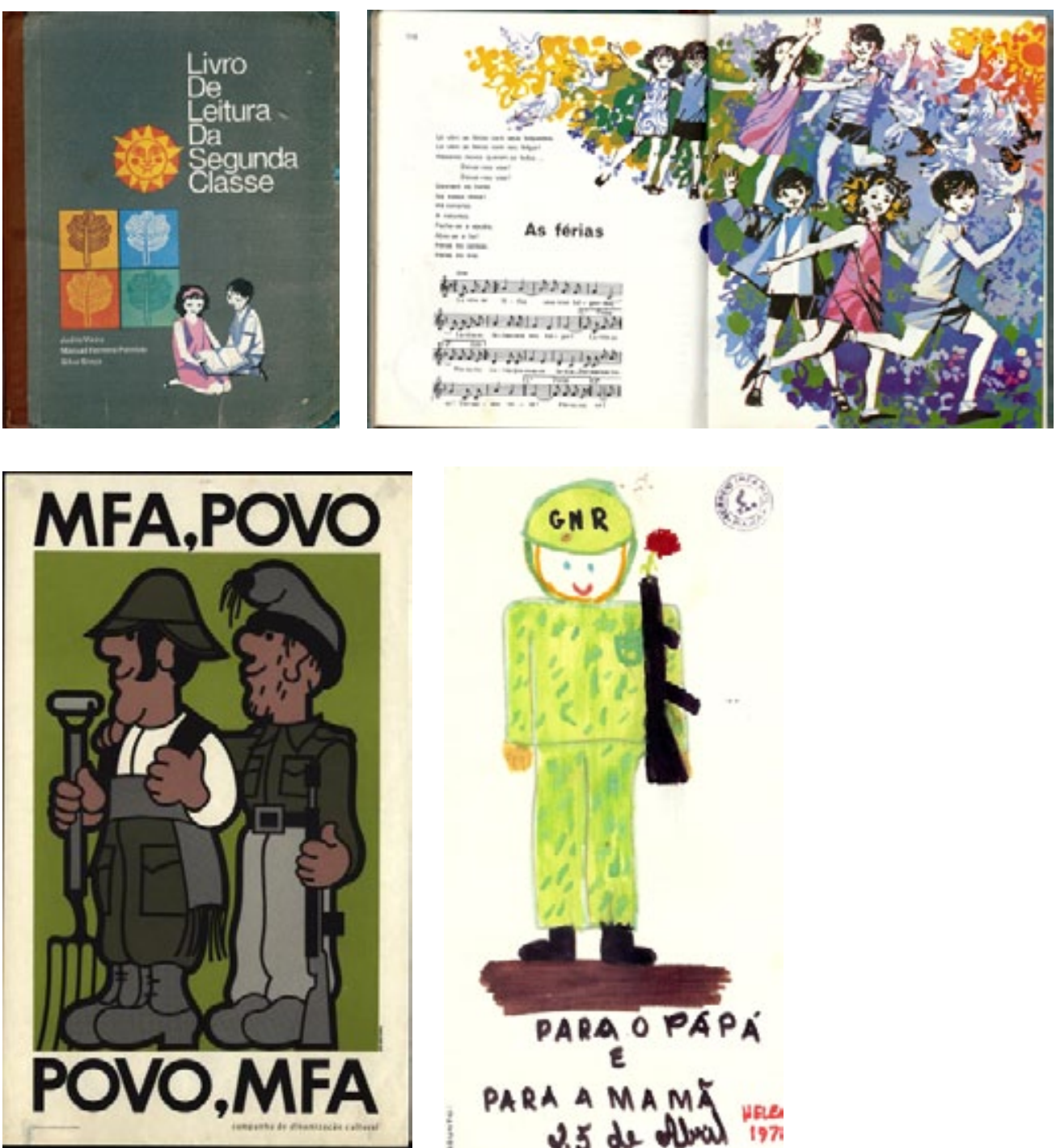

PARA A MAMK 2.5 de Abral 197
Figure 3 y 4. Left: Draw (1978) from the house of Nampula (Mozambique). Right: Draw (1978) from the house of Lourenço Marques (Mozambique). Personal archive.
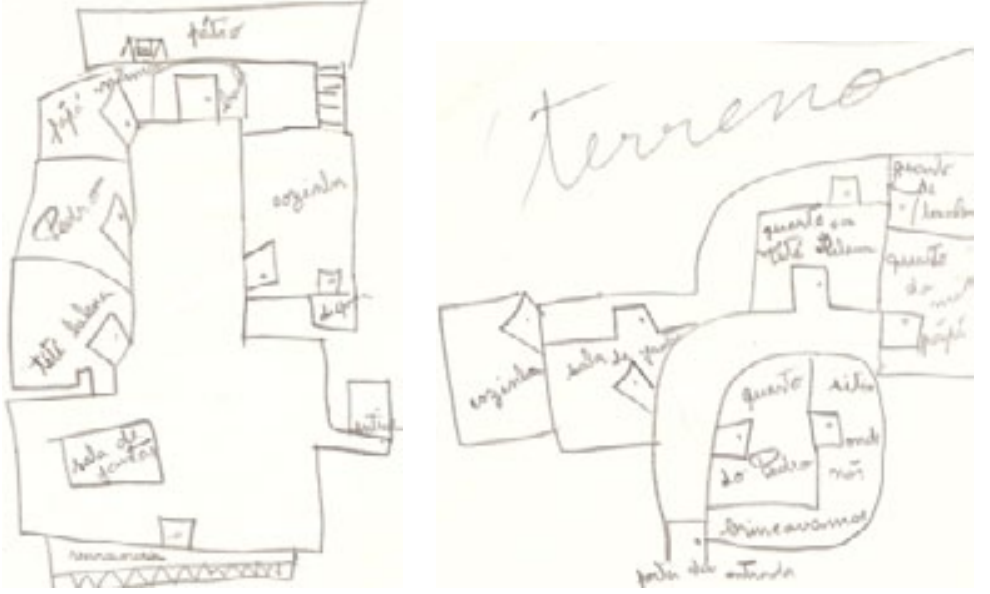
$2^{\circ}$ Congresso Internacional

de Arte, Ilustração e Cultura Visual

na Educação Infantil e Primária

\section{Conclusion}

The historical presentation of some examples of artefacts and experiences within the framework of authorship, constitute significant evidence of the importance of how these contexts are essential to realize the construction of personal identity and professional. It is concluded that the objects that become remarkable on this identity fall mainly on artefacts that date back to a very young age. Consequently, the interpretation of visual and material culture, performed by various authors became important references in the construction of identity. The influence of the authors were materialised subconsciously since childhood, using the drawing as the dominant discourse, proposing the graphic design as a media of excellency and expression of the author of this article.

\section{References}

Ames, K. L. (2000). "Material cultures: why some things matter". Journal of Design History 13/1, p. 74-75.

Attfield, J. (1999). "Beyond the pale: reviewing the relationship between material culture and design history". Journal of Design History 12/4, p. 373-380.

Bonnell, V. E.; Hunt, L. (1999). Beyond the culture turn: new directions in the study of society and culture. Berkeley: University of Califórnia Press.

Clarke, A. J. (2001). "The aesthetics of social aspiration", in D. Miller, ed. Home possessions: material culture behind closed doors. Oxford: Berg.

Fisher, T. H. (2004). "What we touch,touches us: materials, affects and affordances". Design Issues, 20/4, p. 20-31.

Kingery, W. D. (1996). Learning from things: method and material of material culture studies.Washington, D.C.: Smithsonian Institution Press.

Kopytoff, I. (1986). "The cultural biography of things: commoditization as process", in A. Appadurai, ed., The social life of things: commodities in cultural perspective. Cambridge: University Press. 